\title{
Studies on the Antagonistic Effect of Serretia rubidaea for Biofilm Development Capability
}

\author{
Jabun Naher'1, Shahidul A. Chowdhury', Abdullah A. Mamun², Nuruddin Mahmud', \\ Whahida Shumi ${ }^{*}$, Ruhul A. Khan ${ }^{2}$ \\ ${ }^{1}$ Department of Microbiology, University of Chittagong, Chittagong, Bangladesh \\ ${ }^{2}$ Institute of Radiation and Polymer Technology, Bangladesh Atomic Energy Commission, \\ Dhaka, Bangladesh

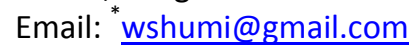

Received 3 April 2014; revised 8 May 2014; accepted 15 May 2014

Copyright (C) 2014 by authors and OALib.

This work is licensed under the Creative Commons Attribution International License (CC BY).

http://creativecommons.org/licenses/by/4.0/

(c) (i) Open Access

\section{Abstract}

This study was performed to compare the growth dynamics of Serretia in single and co-culture biofilms condition and also evaluated its antagonistic effect against pathogenic bacteria. One preserved isolated subculture was identified on the basis of their morphological, cultural and biochemical characteristics. The isolate was belonged to the genus Serretia and provisionally identified as Serretia rubidaea. This isolate was exposed to different environmental condition. The experiments were carried out in Luria Bertani (LB) broth. The growth rate in different environmental parameter was measured by crystal violet staining of bacteria in Spectrophotometer. It was studied the ability of selected microorganism to generate biofilm on the test tube surfaces at different temperatures, $\mathrm{pH}$ values, $\mathrm{NaCl}$ concentrations and medium content. It was found that Serretia grew well at $27^{\circ} \mathrm{C}$ after $48 \mathrm{~h}$ and co-culture grew well at $37^{\circ} \mathrm{C}$ after $24 \mathrm{~h}$. The $0.5 \% \mathrm{NaCl}$ concentration was optimum for both. The results indicated that high concentration of $\mathrm{NaCl}$ clearly inhibited the adherence of the cells to the tube surfaces. Other analysis suggested that $\mathrm{pH} 7$ was required for Serretia but pH 5 was suitable for co-culture. An attempt was also made to detect the inhibitory effects of Ciprofloxacin on the selected isolate and co-culture. It was found that, at $\mathbf{1 0} \boldsymbol{\mu g} / \mathbf{m l a n t i -}$ biotic concentration, the Serretia single culture was more resistant than co-culture. The antagonistic effect of Serretia against pathogen showed that Serretia produced a small zone of inhibition.

\section{Keywords}

Antagonistic Effect, Biofilm, Biosurfactant, Inhibitory Effect, Antimicrobial Properties,

\footnotetext{
*Corresponding author.
} 


\section{Co-Culture}

\section{Introduction}

Biofilms are a collection of microorganisms which are encased within a matrix of organic materials generated by the microbes themselves and attached onto surfaces like plastics, stainless steel, glasses and initiating a growth process [1] [2]. It can be considered as a deposit where microorganisms are highly adhered onto a surface by means of appendages of either protein or polysaccharide nature, referred to as glycocalyx [3] [4]. Such appendage protrudes externally from the outer membrane of gram-negative cells or from the peptideoglycan of gram-positive ones. Under a hydrated state, it contains from 98\% - 99\% of water, thus protecting the cells against dehydration [5]. It has been found to contain water channels that help distribute nutrients and signaling molecules. It has an increased resistance to detergents and antibiotics, and this resistance to antibiotics in both stationary phase cells and biofilms may be due to the presence of persister cells [6]. Lateral gene transfer is greatly facilitated in biofilms and leads to a more stable biofilm structure [7]. Biofilms also provide an ideal niche for the exchange of extra chromosomal DNA (plasmid). Dispersal of cells from the biofilm colony is an essential stage of the biofilm life cycle. Enzymes that degrade the extracellular matrix, such as dispersin B and deoxyribonuclease, may play a role in biofilm dispersal [8] [9]. Biofilm matrix degrading enzymes may be useful as anti-biofilm agents [6] [7]. Like most soft materials biofilms are viscoelastic [10] [11]. A considerable number of both spoilage and pathogenic microorganisms are able to participate at a higher or lower intensity in both adhesion processes and biofilm formation. Pseudomonas aeruginosa [12], Pseudomonas fragi, Micrococcus spp and Enterococcus faecium [3] [4], are some of the spoilage microorganisms while Listeria monocytogenes Yersinia enterocolitica, Salmonella sp, Escherichia coli, Staphylococcus aureus and Bacillus cereus [1] [5] are pathogenic ones. Biofilms play an important role in the ecology of the earth and the sustainability of life. They are capable of solving a huge problem in the cleaning of wastewater and used successfully in water and wastewater treatment for over the century. Other beneficial applications of biofilms are in cleaning up oil and gasoline spills by bioremediation. Biofilm retards water flow and prevents the immediate loss of water from the soil where water scarcity is tremendous. Due to its water retention properties it has a potential use as thickener, expander or viscosity enhancer in a variety of materials including paints, stains, dyes, oils, greases, among many others. Bacterial biofilms are also responsible for several chronic diseases that are difficult to treat. It has been implicated in a variety of human infections such as endocarditis, osteomyelitis, chronic otitis media, gastrointestinal ulcers, urinary tract infections, chronic lung infection, cystic fibrosis in patients, caries, periodontitis, formation of dental plaque, gingivitis [7] and coating on contact lenses [13]. More recently it has been noted that bacterial biofilms may impair cutaneous wound healing and reduce topical antibacterial efficiency in healing or treating infected skin wounds. Biofouling is the detrimental development of biofilms which decrease heat transfer in heat exchangers, increase the pressure drop in pipelines and enhance corrosion. The standard assay for measuring biofilm formation is the crystal violet (CV) assay, which involves quantification of dye bound to cells within a biofilm. Scanning electron microscopy (SEM) has also been used to examine biofilm formation. Serretia is a genus of Gram negative, facultatively anaerobic, rod shaped bacteria of the Enterobacteriaceae. This genus is responsible for about $2 \%$ of nosocomial infections of the bloodstream, lower respiratory tract, urinary tract, surgical wounds, skin and soft tissues in adult patients [14]. They are unique by their production of three enzymes such as DNase, lipase and gelatinase [15].

The objective of the present research was to evaluate the antagonistic activity of single microbial community due to their extracellular protein and secreted enzyme and to observe the effect of environmental parameters for the formation of single and co-culture biofilm and the inhibitory effects of Ciprofloxacin against both culture condition.

\section{Materials and Methods}

\subsection{Materials and the Characteristics of Bacteria Serretia rubidaea}

\subsubsection{Materials}

For the present research work, subcultures of previously isolated bacteria were used. These cultures were kept 
preserved in the laboratory of Microbiology Department, Chittagong University. The preserved culture was then enriched in nutrient broth for $4 \mathrm{hrs}$ at $37^{\circ} \mathrm{C}$ temperature. To confirm the purity of the isolate the enriched culture was seeded onto Nutrient Agar (NA) medium following streak plate method and ensure the presence of similar types of colonies in the medium. To facilitate the handling of the isolate it was designated as NW. One set of purified bacterial subculture was preserved as stock culture in polyethylene bag at $4{ }^{\circ} \mathrm{C}$ temperature. Occasional sub-culturing (after 3 to 4 weeks) was maintained to keep the culture in active condition and used for further studies.

\subsubsection{The Characteristics of Bacteria Serretia rubidaea}

Serratia is a genus of Gram-negative, facultatively anaerobic, rod-shaped bacteria of the Enterobacteriaceae family. The most common species in the genus, $S$. marcescens, is normally the only pathogen and usually causes nosocomial infections. However, rare strains of S. plymuthica, S. liquefaciens, S. rubidaea, and S. odoriferae have caused diseases through infection. The S. rubidaea was described for the first time in 1940 as Bacterium rubidaea and was later reclassified as S. rubidaea. It has been isolated from coconuts and from vegetable salads, but it has not been reported from water, insects, small mammals, or animal territories.

\subsection{Identification}

With an aim to characterize the selected bacterial isolate the renowned morphological and biochemical methods were followed. Based on the results or characteristics obtained from following experiments, the isolate was identified.

\subsection{Biofilm Production and Screening Procedure}

Biofilm production was done by the modified method of Christensen et al. (1982) [16]. In this method, one loopful from the subculture of isolate was inoculated in $5 \mathrm{ml}$ LB broth containing test tubes and incubated for 4 hours at $37^{\circ} \mathrm{C}$ temperature for enrichment. Then the suspension was dispensed in different test tube at inoculum to medium ratio of $1: 20$ and incubated at $37^{\circ} \mathrm{C}$ temperature for different periods $(24,48,72,96$ and 120 hours respectively). After incubation biofilm was seen by staining procedure. The dye used for this purpose was ammonium oxalate crystal violet. Here the assay was done by the modified method [17]. In this assay, after the respective incubation times, the culture medium was discarded from the tubes carefully. Then the tubes washed with sterile distilled water to remove loosely associated bacteria and air dried for 30 minutes. The tubes were stained with 1\% ammonium oxalate crystal violet solution and left for 30 minutes at room temperature. Tubes were then inverted to remove the crystal violet and rinsed twice with sterile distilled water to remove excess crystal violet (CV). Five ml of 95\% ethanol solution was added in each tube which can act as a distaining agent and incubated for 30 minute at room temperature. This could dissociate the bioflim forming cells and solubilized the remaining crystal violet attached to the cell. The absorbance of the retained dye was measured by spectrophotometer at $600 \mathrm{~nm}$.

\subsection{Different Parameters for Biofilm Development}

For the detection of optimum growth parameter the single and co culture organisms were inoculated in different media parameters at inoculums to medium ratio of 1:20. Then the tubes were incubated at different temperatures $\left(10^{\circ} \mathrm{C}, 27^{\circ} \mathrm{C}, 37^{\circ} \mathrm{C}\right.$ and $\left.45^{\circ} \mathrm{C}\right)$ for different incubation time. After incubation the biofilm was assayed by the modified method [17].

\subsection{Antibiotic Sensitivity Pattern of Single and Co-Culture Microorganisms}

The disc diffusion method [18] was used to determine the antibacterial activity of antibiotics against the isolate. The test was done for NW single and co-culture on Mueller-Hinton agar plates. For this purpose, $25 \mathrm{ml}$ of medium was poured into $90 \mathrm{~mm}$ diameter sterile Petri dishes to a depth of $4 \mathrm{~mm}$ on a level surface to make the depth of the medium uniform and left at $37^{\circ} \mathrm{C}$ temperature overnight to check sterility. The MIC (minimum inhibitory concentration) and MBC (minimum bactericidal concentration) was measured only for Ciprofloxacin which is a broad spectrum antibiotic. 


\subsubsection{Inoculum Preparation}

For inoculum preparation $5 \mathrm{ml}$ LB broth was dispensed in screw cap tubes and sterilized by autoclaving at $121^{\circ} \mathrm{C}$ for 20 minutes. The tubes were cooled and kept in an incubator for 24 hours at $37^{\circ} \mathrm{C}$ to check sterility. Then few tubes were inoculated with purified isolate NW and other with 1:1 ratio of NW and pathogenic bacteria. All tubes were placed in an incubator at $37^{\circ} \mathrm{C}$ for 4 hrs. After incubation bacterial suspension was saturated with a sterile cotton bud swab and excess inoculum was removed by turning the swab against the side of the tube. Inoculums were spread evenly over the entire surface of the Mueller-Hinton agar plates by swabbing back and forth across the agar in three directions to give uniform inoculums to the entire surface. Different cotton swab were used for single co-culture bacterial suspension in different Petri plates. These plates were allowed to dry before applying discs. For test discs sterile filter paper discs (Whatman No. 1, $6 \mathrm{~mm}$ ) were impregnated with $(10 \mu \mathrm{g} / \mathrm{disc}, 25 \mu \mathrm{g} / \mathrm{disc}, 50 \mu \mathrm{g} / \mathrm{disc})$ antibiotic solution and left to dry under the laminar flow cabinet for $40 \mathrm{mins}$. These discs were applied on the inoculated plates with the help of a sterile forceps. The forceps was dipped in alcohol and flamed for sterilization. These plates were then placed in a refrigerator at $4^{\circ} \mathrm{C}$ for 3 hours. This temperature could inhibit the growth of the organisms and within this time the antibiotics could diffuse in to the media. Then the plates were placed in an incubator at $37^{\circ} \mathrm{C}$ for $18 \mathrm{hrs}$ in inverted position. After $18 \mathrm{hrs}$ of incubation, plates were examined and the diameters of zone of inhibition were measured in $\mathrm{mm}$.

\subsubsection{MIC and MBC Value Determination}

The minimum inhibitory concentration (MIC) of Ciprofloxacin was determined by using the serial dilution method with LB broth and the final concentrations of antibiotic were $(10 \mu \mathrm{g} / \mathrm{ml}, 25 \mu \mathrm{g} / \mathrm{ml}$ and $50 \mu \mathrm{g} / \mathrm{ml})$. Then 4.75 $\mathrm{ml}$ of different concentrated antibiotic solution were placed in different tubes and autoclaved. The diluted purified and co-culture bacterial suspensions $\left(10^{-1}\right.$ to $\left.10^{-5}\right)$ were added in each tube at a ratio of 1:20. Each antibiotic concentration was assayed in triplicate. The MIC values were taken as the lowest concentration of the antibiotic that showed no turbidity after 24 hours of incubation at $37^{\circ} \mathrm{C}$. The turbidity of the tubes was interpreted as visible growth of the microorganisms. The minimum bactericidal concentration (MBC) was determined by culturing the suspension of the tube showing no apparent growth in a sterile LB agar plate. The least concentration showing no visible growth of isolate and co culture microorganisms was taken as MBC for that antibiotic. In this study MBC was done by drop plate method.

\subsection{Crude Enzyme Preparation and Assay of Selected Isolate}

To obtain crude enzyme 48 hours old culture of isolate was transferred to micro centrifuge tubes and centrifuged at 12,000 rpm for $15 \mathrm{~min}$. Cells were discarded and resultant supernatant was used as the crude enzyme for various enzyme assay. Enzyme assay was done by spectrophotometrically.

\subsubsection{Alkaline Protease Assay}

A $3 \mathrm{ml}$ of the supernatant including $3 \mathrm{ml}$ of alkaline citrate phosphate buffer ( $\mathrm{pH} 8$ ) was mixed with $3 \mathrm{ml}$ of alkaline casein substrate. The mixture was incubated at $40^{\circ} \mathrm{C}$ in water bath for 60 minutes. The solution was mixed with $5 \mathrm{ml}$ trichloro acetic acid $(0.4 \mathrm{M})$. It blocks enzyme activity and precipitates the intact casein. The solution stands for 1 hour at room temperature and was centrifuged in a high speed Hitachi refrigerated centrifuge at 12,000 rpm for $10 \mathrm{~min}$ at $4^{\circ} \mathrm{C}$. Then, $1 \mathrm{ml}$ of supernatant was mixed with $5 \mathrm{ml} \mathrm{Na}_{2} \mathrm{CO}_{3}(0.4 \mathrm{M})$ and $1 \mathrm{ml}$ of Folin-ciocalteau phenol $(0.1 \mathrm{M})$ reagent and was incubated at $40^{\circ} \mathrm{C}$ in water bath for 20 minutes in a dark condition. The mixtures were shaken well and stand for 30 minutes. Six ml distilled water was mixed with this solution and vortexes. Finally, the OD of the mixed solution was measured at $650 \mathrm{~nm}$ wavelength using spectrophotometer [19]-[21].

\subsubsection{Amylase Assay}

This assay was done by using a reaction mixture consisting $1 \mathrm{ml}$ of substrate solution (1.1\% soluble starch in 50 $\mathrm{mM}$ citrate phosphate buffer $\mathrm{pH}$ 7.2) and $100 \mu \mathrm{l}$ of the enzyme solution. The reaction mixture was incubated for $10 \mathrm{~min}$ at $30^{\circ} \mathrm{C}$. Reaction was stopped by adding $2 \mathrm{ml}$ of dinitrosalicyclic acid (DNSA) reagent. The reaction mixture was heated to $100^{\circ} \mathrm{C}$ for 10 min and cooled. Optical density of each sample with reaction mixture was taken at $650 \mathrm{~nm}$ in a spectrophotometer [22]. 


\subsection{Evaluate the Antagonistic Effect of Selected Isolate}

Antagonistic activity of purified isolate against pathogenic bacteria was determined by disc diffusion method. To evaluate antagonistic effect 24 hrs incubated culture broth of isolate was transferred to micro centrifuge tubes and centrifuged at 12,000 rpm for $15 \mathrm{~min}$. Pilot were discarded and resultant cell free supernatant (CFS) was used to assays the antagonistic activity. Pure pathogenic bacteria colony was picked with a sterile cotton bud swab and was spread over the entire surface of different nutrient agar plates in a manner to give a uniform inoculum to the entire surface was allowed to dry. After drying Whatman No. 1 filter paper disc saturated with supernatant of NW was placed in seeded plate and incubate for 24 hours at $37^{\circ} \mathrm{C}$. A clear zone of inhibition around the disc was then measured.

\subsection{Statistical Analysis}

Each test was replicated at least five times. The values presented here is the average of five samples.

\section{Results and Discussion}

The morphological, cultural and biochemical characteristics of the preserved isolate was studied to identify it up to species. Morphological characteristics include size and shape, arrangement of the cells, presence or absence of spores, irregular forms, acid fast reaction, gram reaction. Cultural and physiological characteristics include temperature tolerance, salt tolerance, IMViC test, $\mathrm{H}_{2} \mathrm{~S}$ production, nitrate reduction test, fermentation of different carbohydrates. All these characteristics were then compared with the standard description of "Bergey's Manual of Determinative Bacteriology" and found that the isolates belong to the genus Serretia. Results are presented in Table 1. The optimum growth parameters for biofilm formation by single and coculture situation of Serretia showed that between 24 and 48 hours incubation period at different temperatures, the single culture was denser and more vigorous than their counterpart coculture condition as depicted in Table 2. Co-culture always showed less absorbance than Serretia. But Serretia showed high absorbance at $27^{\circ} \mathrm{C}$ temperature for 48 hours. Here negative control was deducted from the test absorbance. These results are in accordance with the published values reported in the journal [23]. According to their study Serretia showed antimicrobial activity towards the pathogenic microorganisms and produced anti-biofilm potential glycolipid surfactant.

A large difference was observed in biofilm formation in various $\mathrm{pH}$ ranges. After adjusting the media $\mathrm{pH}$ such as $\mathrm{pH}$ 4, 5, 7, 8 and 9 (before autoclave) it was found that at $\mathrm{pH}$ 7, the growth of Serretia was increased while coculture showed extended growth in $\mathrm{pH} 5$. In acidic $\mathrm{pH}$ level (pH 3), coculture interestingly produced biofilm (OD at $600 \mathrm{~nm}<0.1$ ). On the other hand, at a high alkaline $\mathrm{pH}$ level (pH 9), Serretia showed its potentiality in biofilm production. The results are presented in Table 3. It was postulated that molecular interactions between charged acidic groups in the biofilm slimeand the bacterial cell walls contracted the biofilm and permitted them to grow at acidic $\mathrm{pH}$ in the coculture condition.

The effects of salt concentration on the biofilm formation showed that the medium with $0.5 \%$ salt having a good growth for both Serretia and coculture. But when the salt concentration was doubled, they showed less absorbance. The findings are represented in Table 4.

Other parameter such as medium content showed that at $0.5 \%$ media content coculture grew well. But Serretia grew well at $2 \%$ media content (Table 5 ).

Minimum inhibitory concentration (MIC) is the lowest concentration of drugs at which no bacterial growth was visually observed after incubation at $37^{\circ} \mathrm{C}$ for 24 hours. In this study, it was performed by micro dilution method at concentration of 10, 25 and $50 \mu \mathrm{g} / \mathrm{ml}$. The MIC result was given in Table 6. The highest growth was found in $10 \mu \mathrm{g} / \mathrm{ml}$ at $10^{-1}$ dilution for Serretia single culture. Only pathogenic bacteria showed growth at increased concentration of antibiotic ( $50 \mu \mathrm{g} / \mathrm{ml})$ but in coculture condition no growth was found at same concentration. Zone of inhibition by Serretia and coculture $\left(10^{-1}\right.$ and $10^{-2}$ dilution) at 10,25 and $50 \mu \mathrm{g} /$ disc antibiotic concentrations are presented in Figure 1 and Figure 2. Figures illustrated that at $10^{-1}$ dilution Serretia showed higher inhibition zone than co-culture and at $10^{-2}$ dilution the growth was scattered in co-culture. Melphine et al. [24] demonstrated that co-cultures could cause an antibiotic susceptibility that differs from one of the pure cultures. The results found in this study were similar to the findings of Melphine et al. The co-culture biofilm showed lower growth as well as lower resistance than Serretia in $10 \mu \mathrm{g} / \mathrm{ml}$ at $10^{-1}$ and $10^{-2}$ dilution.

The antimicrobial property of the selected isolate was determined by the disc diffusion assay (DDA) method. 
Table 1. Morphological, cultural, biochemical and physiological characteristics of the isolate NW.

\begin{tabular}{|c|c|}
\hline Parameters & Observations \\
\hline Agar colonies & $\begin{array}{l}\text { Whitish, yellowish, circular, entire, } \\
\text { convex, smooth colonies }\end{array}$ \\
\hline Agar slant & Filiform \\
\hline Broth culture & Turbidity found \\
\hline Gram staining & Gram negative \\
\hline Spore staining & Non spore-former \\
\hline Shape & Short rod, cocci \\
\hline Cell arrangement & Single, sometimes pair \\
\hline Size & Length-1.54 $\mu \mathrm{m}$, Width- $0.98 \mu \mathrm{m}$ \\
\hline Motility test & Positive \\
\hline Deep glucose agar test & Facultative anaerobes \\
\hline Glucose fermentation & Dark greenish \\
\hline Xylose fermentation & Bluish (alkaline) \\
\hline Arabinose fermentation & Bluish (alkaline) \\
\hline Lactose fermentation & Bluish (alkaline) \\
\hline Sucrose fermentation & Bluish (alkaline) \\
\hline Mannitol fermentation & Greenish (acidic) \\
\hline Indole test & Positive \\
\hline $\mathrm{H}_{2} \mathrm{~S}$ production & Negative \\
\hline Urease test & Negative \\
\hline Oxidase test & Positive \\
\hline Citrate test & Positive \\
\hline Catalase test & Highly positive \\
\hline Methyl red reaction & Positive \\
\hline Voges-proskaur & Positive \\
\hline Nitrate reduction test & Positive \\
\hline Inorganic salt & Negative (-) \\
\hline Glucose hydrolysis & Greenish \\
\hline Casein hydrolysis & Positive (+) \\
\hline Starch hydrolysis & Positive (+) \\
\hline Gelatin hydrolysis & Positive (+) \\
\hline
\end{tabular}

Identification: The morphology, cultural and biochemical characteristics of isolate NW was found to closely related with the genus Serretia while compared with the description given in "Bergey's Manual of Determinative Bacteriology" ( $8^{\text {th }}$ ed. Buchanon and Gibbons 1974) and provisionally identified as Serretia rubidaea. But it differed with the standard description in oxidase test, $\mathrm{H}_{2} \mathrm{~S}$ production and Gelatin hydrolysis. 
Table 2. Effects of different temperature during 24 and 48 hours incubation period. Here biofilm formation is measured by crystal violet absorbance at $600 \mathrm{~nm}$.

\begin{tabular}{|c|c|c|c|c|c|c|}
\hline \multirow{3}{*}{ Microorganisms } & \multicolumn{6}{|c|}{ Absorbance at different temperature for different incubation period } \\
\hline & \multicolumn{3}{|c|}{24 hours } & \multicolumn{3}{|c|}{48 hours } \\
\hline & $37^{\circ} \mathrm{C}$ & $27^{\circ} \mathrm{C}$ & $10^{\circ} \mathrm{C}$ & $37^{\circ} \mathrm{C}$ & $27^{\circ} \mathrm{C}$ & $10^{\circ} \mathrm{C}$ \\
\hline Serretia & 0.292 & $0.397^{*}$ & $0.171^{*}$ & $0.354^{*}$ & $0.569^{*}$ & $0.128^{*}$ \\
\hline Co-culture & 0.180 & 0.255 & 0.155 & 0.116 & 0.219 & 0.177 \\
\hline
\end{tabular}

Note: "Indicate the highest absorbance.

Table 3. Absorbance at $600 \mathrm{~nm}$ with different media $\mathrm{pH}$ after optimum incubation period with optimum temperature.

\begin{tabular}{cccccc}
\hline Microorganisms & $\mathrm{pH} 4$ & $\mathrm{pH} 5$ & $\mathrm{pH} \mathrm{7}$ & $\mathrm{pH}$ & $\mathrm{pH} \mathrm{9}$ \\
\hline Serretia & 0.154 & 0.552 & $0.759^{*}$ & $0.491^{*}$ & $0.159^{*}$ \\
Co culture & $0.551^{*}$ & 0.638 & 0.397 & 0.224 & 0 \\
\hline
\end{tabular}

Note: *Indicate the highest absorbance.

Table 4. Absorbance at $600 \mathrm{~nm}$ with different salt concentration after optimum incubation period.

\begin{tabular}{ccccc}
\hline & \multicolumn{4}{c}{ Different Concentration } \\
Microorganism & $0 \%$ & $0.5 \%$ & $1 \%$ & $2 \%$ \\
\cline { 2 - 4 } Serretia & 0.311 & 0.808 & 0.397 & $0.199^{*}$ \\
Co culture & 0.137 & 1.105 & 0.180 & 0.135 \\
\hline
\end{tabular}

Note: "Indicate the highest absorbance.

Table 5. Absorbance at $600 \mathrm{~nm}$ with different media content after optimum incubation period.

\begin{tabular}{cccc}
\hline & & Medium Content \\
Microorganism & $0.5 \%$ & $1 \%$ & $2 \%$ \\
\hline Serretia & 0.320 & 0.397 & $1.603^{*}$ \\
Co culture & 0.843 & 0.180 & 0.117 \\
\hline
\end{tabular}

Note: *Indicate the highest absorbance.

Table 6. Growth pattern (absorbance) of selected microorganism and coculture ( $10^{-1}$ and $10^{-2}$ dilution) at different antibiotic concentration.

\begin{tabular}{|c|c|c|c|c|c|c|}
\hline \multirow{3}{*}{$\begin{array}{c}\text { Selected } \\
\text { microorganisms }\end{array}$} & \multicolumn{6}{|c|}{ Antibiotic at different concentration $(\mu \mathrm{g} / \mathrm{ml})$ Absorbance at $600 \mathrm{~nm}$} \\
\hline & \multicolumn{2}{|c|}{$10 \mu g$} & \multicolumn{2}{|c|}{$25 \mu \mathrm{g}$} & \multicolumn{2}{|c|}{$50 \mu \mathrm{g}$} \\
\hline & $10^{-1}$ dilution & $10^{-2}$ dilution & $10^{-1}$ dilution & $10^{-2}$ dilution & $10^{-1}$ dilution & $10^{-2}$ dilution \\
\hline Pathogen & 0.224 & 0.181 & 0.159 & 0.97 & 0.06 & 0.03 \\
\hline Serretia & 0.254 & 0.126 & 0.071 & 0.02 & 0 & 0 \\
\hline Coculture & 0.223 & 0 & 0.085 & 0.079 & 0 & 0 \\
\hline
\end{tabular}




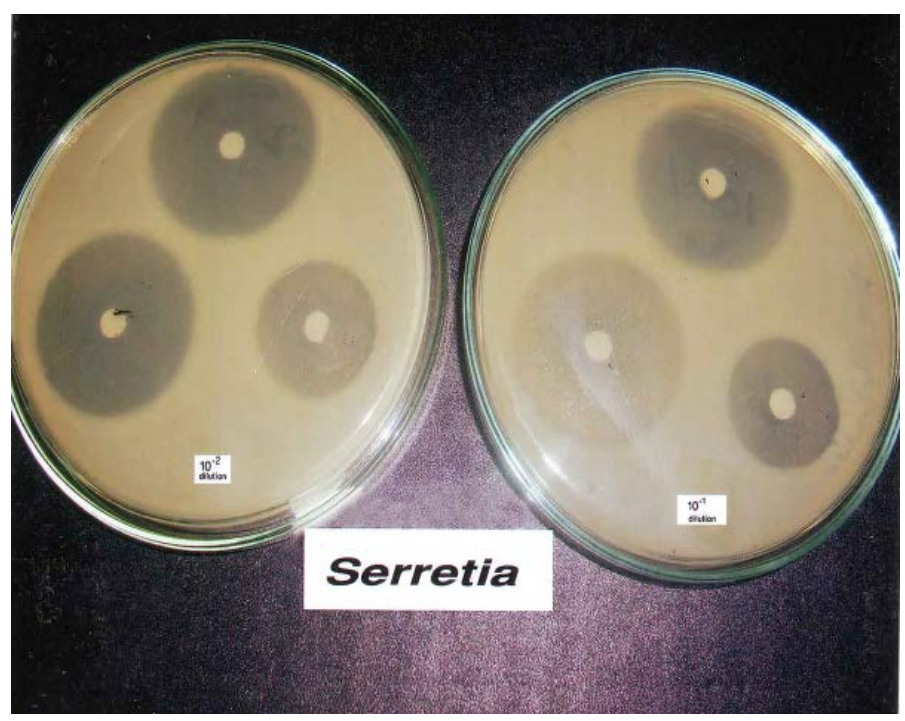

Figure 1. Zone of inhibition produced by NW (Serretia rubidaea) at different dilution.

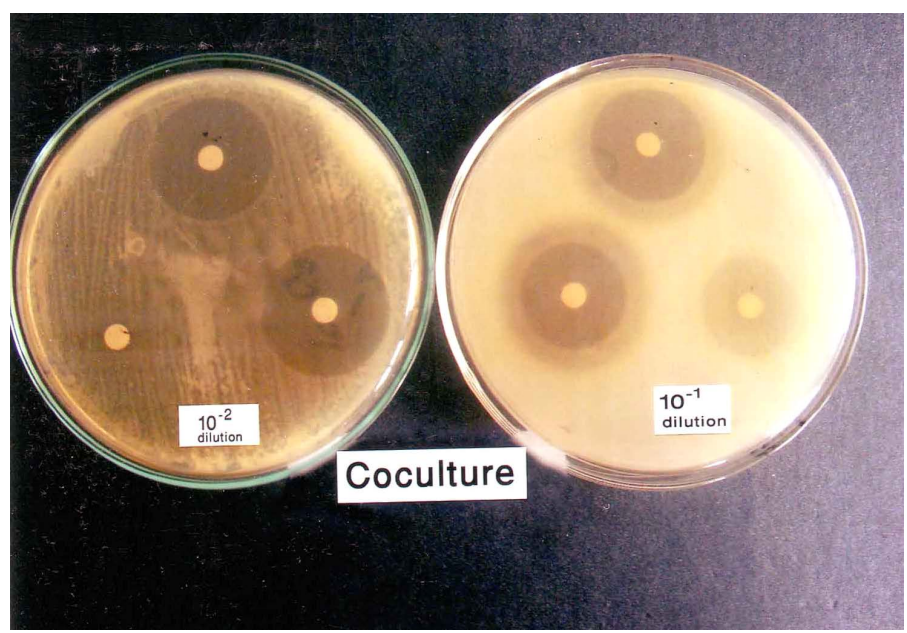

Figure 2. Zone of inhibition produced by coculture at different dilution.

The CFS (cell free supernatant) of the isolate (Serretia rubidaea) can reduce biofilm forming potential and antagonistic to other microorganisms. The zone diameters were found to be 11,13 and $10 \mathrm{~mm}$ respectively, when $10 \mathrm{ml}$ aliquots of the CFS were used. It was carried out the overall activity of the Serretia strain of various enzymatic screening to observe which type of enzyme had antagonistic effect. The overall activities were as follows: caseinase, amylase (starch), and lipolytic. Lipid hydrolysis was not shown by the strain. But the caseinase and amylase activities were shown by the strain. The result showed that Serretia produced starch and caseinase after 18, 24 and 48 hours of incubation (Figure 3). The absorbance of starch was 0.099, 0.41 and 0.002 but $0.111,0$ and 0 absorbances were found for caseinase. Finally, this is clear that after 24 hours of incubation, no caseinase activity was observed.

\section{Conclusion}

The growth dynamics of Serretia in single and co-culture biofilms condition was compared and evaluated the antagonistic effect against pathogenic bacteria. The cell free supernatant of the Serretia rubidaea can reduce biofilm forming potential and antagonistic to other microorganisms. It can be concluded that Serretia may produce 


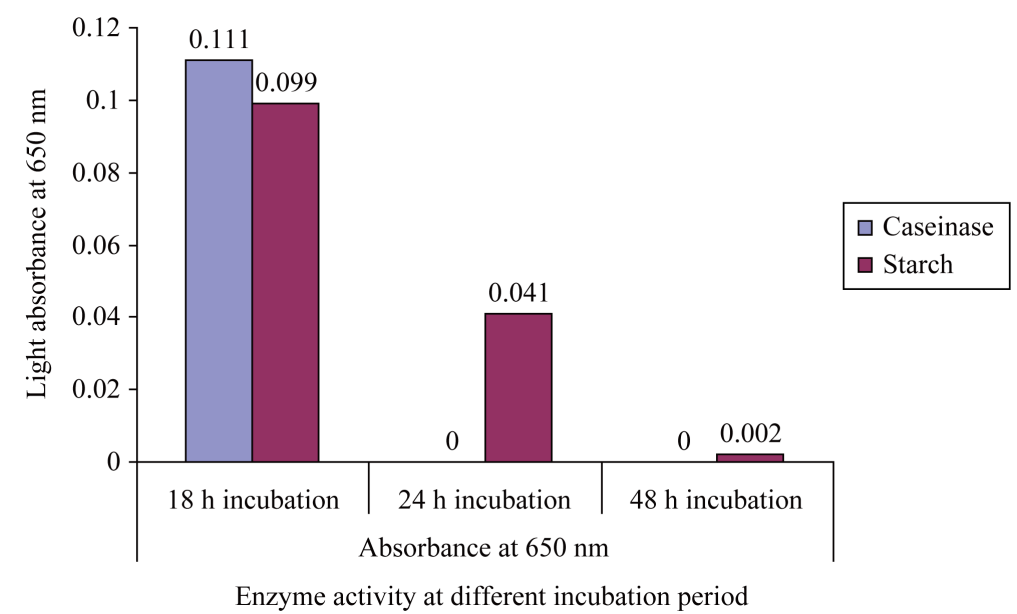

Figure 3. Enzyme activity showed that Serretia produce starch $(0.099,0.41$ and 0.002$)$ and caseinase $(0.111,0$ and 0$)$ after 18, 24 and 48 hours of incubation.

biosurfactant type product which may be amylase in nature. It was also revealed the inhibitory effect of Ciprofloxacin between Serretia single and co-culture condition. Further development of this bio-surfactant may be used as an antimicrobial agent against pathogen.

\section{References}

[1] Pompermayer, D.M.C. and Gaylarde, C.C. (2000) The Influence of Temperature on the Adhesion of Mixed Cultures of Staphylococcus aureus and Escherichia coli to Polypropylene. Food Microbiology, 17, 361-365. http://dx.doi.org/10.1006/fmic.1999.0291

[2] Zottola, E.A. and Sasahara, K.C. (1994) Microbial Biofilms in the Food Processing Industry: Should They Be a Concern. International Journal of Food Microbiology, 23, 125-148. http://dx.doi.org/10.1016/0168-1605(94)90047-7 http://www.sciencedirect.com/science/article/pii/0168160594900477?via=ihub

[3] Criado, M.T., Suarez, B. and Ferreros, C.M. (1994) The Importance of Bacterial Adhesion in Dairy Industry. Journal of Food Technology, 48, 123-126. http://agris.fao.org/agris-search/search.do?recordID=US19950029470

[4] Potera, C. (1996) Biofilms Invade Microbiology. Science, 273, 1795-1797. http://dx.doi.org/10.1126/science.273.5283.1795

[5] Morton, L.H.G., Greenway, D.L.A., Gaylarde, C.C. and Surman, S.B. (1998) Consideration of Some Implications of the Resistance of Biofilms to Biocides. International Biodeterioration \& Biodegradation, 41, 247-259. http://www.sciencedirect.com/science/article/pii/S0964830598000262

[6] Kaplan, J.B., Ragunath, C., Ramasubbu, N. and Fine, D.H. (2003) Detachment of Actinobacillus actinomycetemcomitans Biofilm Cells by an Endogenous Beta-Hexosaminidase Activity. Journal of Bacteriology, 185, 4693-4698.

http://dx.doi.org/10.1128/JB.185.16.4693-4698.2003 http://www.ncbi.nlm.nih.gov/pmc/articles/PMC166467/

[7] Xavier, J.B., Picioreanu, C., Rani, S.A., Loosdrecht, M.C. and Stewart, P.S. (2005) Biofilm-Control Strategies Based on Enzymic Disruption of the Extracellular Polymeric Substance Matrix: A Modelling Study. The Journal of Microbiology, 151, 3817-3832. http://dx.doi.org/10.1099/mic.0.28165-0 http://mic.sgmjournals.org/content/151/12/3817.abstract

[8] Kaplan, J.B., Ragunath, C., Velliyagounder, K., Fine, D.H. and Ramasubbu, N. (2004) Enzymatic Detachment of Staphylococcus epidermidis Biofilms. Antimicrobial Agents and Chemotherapy, 48, 2633-2636. http://dx.doi.org/10.1128/AAC.48.7.2633-2636.2004 http://www.ncbi.nlm.nih.gov/pmc/articles/PMC434209/

[9] Izano, E.A., Amarante, M.A., Kher, W.B. and Kaplan, J.B. (2008) Differential Roles of Poly-N Acetylglucosamine Surface Polysaccharide and Extracellular DNA in Staphylococcus aureus and Staphylococcus epidermidis Biofilms. Applied and Environmental Microbiology, 74, 470-476. http://dx.doi.org/10.1128/AEM.02073-07 http://www.ncbi.nlm.nih.gov/pmc/articles/PMC2223269/

[10] Christensen, B.E. and Charaeklis, W.C. (1990) Physical and Chemical Properties of Biofilms. In: Characklis, W.C. and 
Marshall, K.C., Eds., Biofilms, John Wiley and Sons Inc, New York, 93-130. http://www.bioline.org.br/pdf?ej06054

[11] Stoodley, P., Lewandowski, Z., Boyle, J.D. and Lappin, H.M. (1999) Structural Deformation of Bacterial Biofilms Caused by Short Term Fluctuations in Flow Velocity: An In-Situ Demonstration of Biofilm Viscoelasticity. Biotechnology and Bioengineering, 65, 83-92.

http://onlinelibrary.wiley.com/doi/10.1002/\%28SICI\%291097-0290\%2819991005\%2965:1\%3C83::AID-BIT10\%3E3. $\underline{0 . C O ; 2-B / a b s t r a c t}$

[12] Brown, M.R.W. and Gilbert, P. (1993) Sensitivity of Biofilms to Antimicrobial Agents. Journal of Applied Bacteriology, 74, 87-97. http://dx.doi.org/10.1111/j.1365-2672.1993.tb04345.x http://jac.oxfordjournals.org/content/44/5/601.full.pdf

[13] Imamura, Y., Chandra, Y. and Mukherjee, P.K. (2008) Fusarium and Candida albicans Biofilms on Soft Contact Lenses: Model Development, Influence of Lens Type, and Susceptibility to Lens Care Solutions. Antimicrobial Agents and Chemotherapy, 52, 171-182. http://dx.doi.org/10.1128/AAC.00387-07 http://www.ncbi.nlm.nih.gov/pmc/articles/PMC2223913/

[14] Adegbola, R.A. (1982) New Fimbrial Hemagglutinin in Serratia Species. Infection and Immunity, 38, 306-315. http://www.ncbi.nlm.nih.gov/pmc/articles/PMC347733

[15] Ursua, P.R., Unzaga, M.J. and Melero, P. (1996) Serratiarubidaea as an Invasive Pathogen. Journal of Clinical Microbiology, 34, 216-217. http://jcm.asm.org/content/34/1/216

[16] Christensen, G.D., Simpson, W.A., Bisno, A.L. and Beachey, E.H. (1982) Adherence of Slime-Producing Strains of Staphylococcus epidermidis to Smooth Surfaces. Infection and Immunity, 37, 318-326. http://www.ncbi.nlm.nih.gov/pubmed/6179880

[17] Biørnstad, T.J. and Håvarstein, L.S. (2011) ClpC Acts as a Negative Regulator of Competence in Streptococcus thermophilus. Microbiology, 157, 1676-1684. http://dx.doi.org/10.1099/mic.0.046425-0 http://mic.sgmjournals.org/content/157/6/1676.full.pdf

[18] Bauer, A.W., Kirby, W.M., Sherris, J.C. and Turck, M. (1996) Antibiotic Susceptibility Testing by a Standardized Single Disk Method. American Journal of Clinical Pathology, 45, 493-496. http://www.ncbi.nlm.nih.gov/pmc/articles/PMC444242/

[19] Joo, H.S., Kumar, C.G., Park, G.C., Kim, T.K., Paik, S.R., Chang, C.S. (2002) Optimization of the Production of an Extracellular Alkaline Protease from Bacillus horikoshii. Process Biochemistry, 38, 155-159. http://dx.doi.org/10.1016/S0032-9592(02)00061-4

[20] Jeong, K.C., Jeong, H.S., Rhee, J.H., Lee, S.E., Chung, S.S., Starks, A.M., Escudero, G.M. and Choi, S.H. (2000) Construction and Phenotypic Evaluation of a Vibrio Vulnificus vvpE Mutant for Elastolytic Protease. Infection and Immunity, 68, 5096-5106. http://dx.doi.org/10.1128/IAI.68.9.5096-5106.2000 http://www.straininfo.net/sequences/AF102028

[21] Singh, J., Vohra, R.M. and Sahoo, D.K. (2004) Introduced Production of Alkaline Proteases by Bacillus sphareicus Using Fed-Batch Culture. Process Biochemistry, 39, 1093-1101. http://dx.doi.org/10.1016/S0032-9592(03)00217-6

[22] Miller, J.H. (1972) Experiments in Molecular Genetics. Cold Spring Harbor Laboratory, Cold Spring Harbor, 466. https://openlibrary.org/books/OL5298363M/Experiments_in_molecular_genetics

[23] Devendra, H.D., Vinay, S.P., Nancharaiah, Y.V., Venugopalan, V.P., Kumar, R.A. and Zinjarde, S.S. (2011) AntiBiofilm Potential of a Glycolipid Surfactant Produced by a Tropical Marine Strain of Serratia marcescens. Biofouling, 27, 645-654. http://dx.doi.org/10.1080/08927014.2011.594883 http://www.academia.edu/734032/Anti-biofilm_potential_of_a_glycolipid_surfactant_produced_by_a_tropical_marine _strain_of_Serratia_marcescens

[24] Melphine, M. and Mairi, C.N. (2009) Candida albicans and Staphylococcus aureus Form Polymicrobial Biofilms: Effects on Antimicrobial Resistance. Antimicrobial Agents and Chemotherapy, 53, 3914-3922.

http://www.ncbi.nlm.nih.gov/pmc/articles/PMC2737866/ 